introditued by Irish nimembers in the present session of Parliament to carry out some of these recommendations. It is impossible toexaggerate the importance of this question. The economic aspect of the drink problem has been well dealt with by Mr. Whitaler, M.P., in the Lees and Roper Memorial Lecture, delivered by him in St. James' IIall, April, 25th, 1902, to which I intist refer those who are interested in this subject. Let me quote his concluding words: "If I have convinced you that civilization itself is menaced by this growing economic waste, let is each and all determine that, so far as in us lies, we will spare no effort to remove this gigantic evil from our nindst, dnd wipe out the stain of this mational degradation."

6.-The Housing of the People of Ireland during the period 1841-1901.

BY

Robert E. Matheson, ESQ., LL.D., Barrister-at-Law, Registrar General for Ireland.

[Read Friday, 5th June, 1903.]

I PURPOSE this evening presenting to the Society a short review of the results of the inquiries made at each successive decennial Census from $184 \mathrm{I}$, into the class of Houses in Ireland, and the accommodation afforded by them, with some observations regarding the results of the special investigation into the number of Tenements of less than five rooms made in connection with the Census of Igor.

\title{
Classification of Houses.
}

An inquiry into the number of houses in Ireland was instituted both in I82I and I83I, in connection with the Census, but no attempt was made to ascertain the class of houses returned, or the accommodation afforded. The Commissioners of I 84I perceived the necessity for some effort in this direction, and framed a scheme of House Classification which has since been adopted at each successive Census." The plan of classification may be thus described:-

The value or condition of a house, as to its quality, may be considered to depend mainly on :-

Ist. Its extent, as shown by the number of rooms.

2nd. Its quality, as shown by the number of its windows, and

* As in the Census Tables for 1871 , the classification adopted on previous occasions was departed from to a certain extent, the figures for that year have been omitted from this paper, they not being fairly comparable with those of preceding and subsequent Censuses. 
3 rd. Its solidity or durability, as shown by the material of its walls and roof.

If numbers be adopted to express the position of every house in a scale of each of these elements, and if the numbers thus obtained for every house be added together, a new series of numbers will be produced, giving the position of each house in a scale compounded of all the elements, i.e., their actual state.

Four classes have been adopted, and the result is, that in the lowest of the four classes are comprised houses built of mud or perishable material, having only one room and window; in the third a better description of house, varying from one to four rooms and windows; in the second what might be considered a good farm house, having from five to nine rooms and windows; and in the first class all houses of a better description than the preceding.

\section{Houses-Whole of Ireland.}

During the 60 years from I 84 I to I9OI, there was a gradual reduction in the total number of houses-a result to have been anticipated from the reduction of the populationthe number of houses having fallen from I, 328,839 in I $84 \mathrm{I}$ to 858,158 in $190 \mathrm{I}$.

There was also a great alteration in the relative number of the houses of each class. Thus in $184 \mathrm{I}$ the fourth class or mud cabins which in that year numbered 49I,278 formed 36.97 per cent. of the total number of houses. In $185 \mathrm{I}$ the number fell to $\mathrm{I} 35,589$, and the percentage to 12.96 , and since then there has been a gradual decline until, in I9OI, we find that of inhabited houses in Ireland there were only 9,873 or I I 5 per cent. belonging to the fourth class.

In considering this decline, it must be borne in mind that in this period Ireland passed through one of the saddest epochs in her history, the years of the terrible Famine, occasioned by the failure of the potato crop, accompanied and succeeded by the Fever and Pestilence which proved so fatal to the poor inhabitants of these cabins. Everywhere throughout the west and south of Ireland, vast numbers of these wretched little habitations were left desolate, the inmates having either perished from the famine or the fever, or sought refuge from their misery in emigration.

Of houses of the 3 rd class there were, in $1841.533,297$ being 40.13 per cent. of the total number of inhabited houses in that year. In I $85 \mathrm{I}$ the number rose to $54 \mathrm{I}, 7 \mathrm{I} 2$ or 51.78 per cent. of the total. In $186 \mathrm{I}$ the number of houses of this class fell to 489,668 , and the percentage to 49.20 since which date each Census shows a further decline. At the date of the last enumeration, the number of houses 
of this class was 251,606 being 29.32 per cent of the total number of inhabited houses in the country.

Notwithstanding the great decline in the population the number of the 2nd class houses gradually increased from 264,184 or 19.88 per cent. of the total number of inhabited houses in 1841 to 521,454 or 60.76 per cent. in I $90 \mathrm{I}$.

The first-class houses which in I84I numbered only 40,080 or 3.02 per cent. had risen in 1901 to 75,225 or 8.77 per cent. of the total number of inhabited houses.

The following Diagram shows graphically the percentage of each class of house in Ireland in the years I84I, I 86I, I 88I and I90I respectively.

\section{INHABITED HOUSES OF EACH CLASS IN IRELAND.}

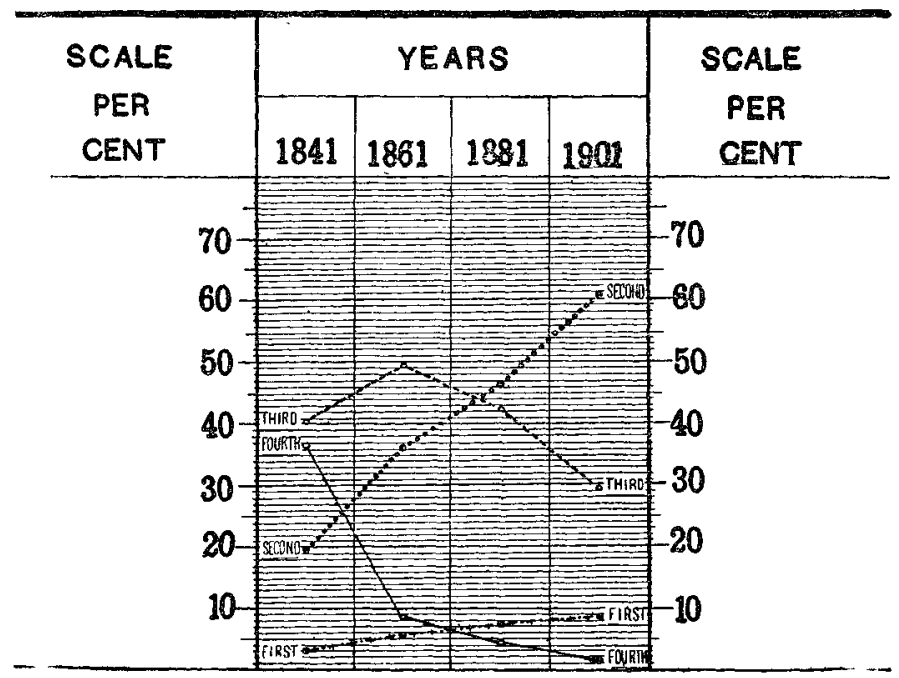

Houses in Civic Districts and Rural Districts.

It has been customary in each census to show the houses by Civic and Rural Districts, the former consisting of towns with 2,000 or more inhabitants, and the Rural Districts comprising all other parts of the country.

\section{Civic 1)istricts.}

The total number of inhabited houses in Civic Districts which in $184 \mathrm{I}$ was $15 \mathrm{I}, 38 \mathrm{I}$ showed an increase at each successive census (185I excepted), till 190I, when it reached 23 I, II 2 .

In $184 \mathrm{I}$ the houses of the $4^{\text {th }}$ class in these districts numbered 20,729 or 13.69 per cent. of the total number 
of inhabited houses. In 185 I they fell to 4,833 or 3.22 per cent., in $186 \mathrm{I}$ to $3,58 \mathrm{I}$ or 2.23 per cent., and they continued to decrease till I9OI, when they were only 527 or 0.23 per cent, of the inhabited houses.

Of third class houses in $184 \mathrm{I}$ there were 40,488 or 26.75 per cent. of the total inhabited houses. There was a slight increase in I $85 \mathrm{I}$, when they were 40,955 or $27.3 \mathrm{I}$ per cent. They have decreased at each Census since that date. In I 86I the number was 38,943 or 24.32 per cent., in I $88 \mathrm{I}, 32,143$ or I 7.01 per cent., in I $891,26,137$ or I 3.03 per cent., while in 1901 it fell to 22,268 or 9.64 per cent.

There were 66,062 second class houses in civic districts in $184 \mathrm{I}$, representing 43.64 per cent of the total inhabited houses in these districts. This number increased to 76,243 or 50.83 per cent. in $\mathrm{I} 85 \mathrm{I}$. In $\mathrm{I} 86 \mathrm{I}$ it rose to 88,037 or 54.97 per cent. In I88 I, houses of this class numbered I 21,707 or 64.39 per cent.; in I 89 I they amounted to I 39,909 or 69.76 per cent.; and at the last Census, 1901, they reached I 7 I,792 or 74.33 per cent.

Houses of the first-class in Civic Districts show a continuous rise in number at each Census during the period I 84 I-I 90 I. In I 84 I they numbered 24, IO2 or I 5.92 per cent. of the total number of inhabited houses, while in I9OI, the number stood at 36,525 , representing a percentage of $15 \cdot 80$.

The following Diagram shows graphically the changes to which I have referred.

\section{INHABITED HOUSES OF EACH CLASS IN OIVIO DISTRIOTS.}

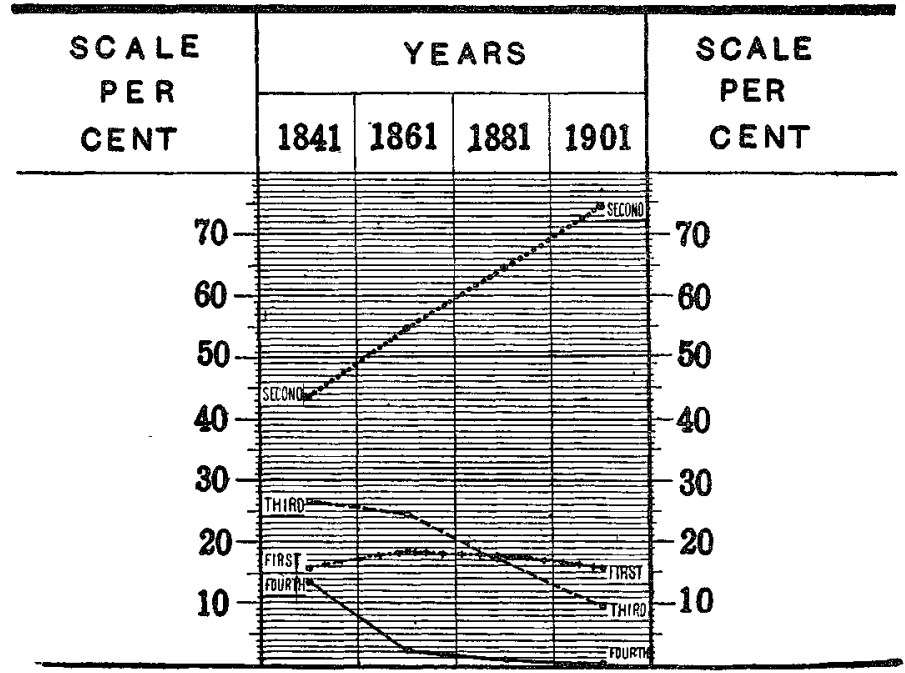




\section{Rural Districts.}

The total number of inhabited houses in Rural Districts shows a continuous decrease at each Census from I84I to I9OI. In the former year I,I 77,458 inhabited houses were enumerated, in $185 \mathrm{I}$ the number fell to 896,237 , in $\mathrm{I} 86 \mathrm{I}$ to $835,00 \mathrm{I}$, and in $\mathrm{I} 88 \mathrm{I}$ to $725, \mathrm{III}$. There was a further decrease in 1891 to 670,017 , and in 1901 to 627,046 .

The inhabited houses of the fourth class in Rural Districts in $184 \mathrm{I}$ numbered 470,549 or 39.96 per cent. of the total inhabited houses. They fell in I 85 I to I 30,756 or 14.59 per cent., in 186 I to 85,793 or 10.28 per cent. in 1881 to 38,804 or 5.35 per cent. In 1891 the number had fallen to 19,761 or 2.95 per cent., and in 1901 it was only 9,346 or $\mathbf{I} .49$ per cent.

In 1841 there were 492,809 houses of the 3 rd class in Rural Districts, representing $4 \mathrm{I} .85$ per cent. of the total inhabited houses in such districts. In 185 I the number rose to 500,757 or 55.87 per cent. of the total. Each subsequent Census showed a decrease, and in rgor the number had fallen to 229,338 or $36.5^{8}$ per cent. of the total.

Houses of the second class show a continuous increase from $184 \mathrm{I}$ to $190 \mathrm{r}$. In $184 \mathrm{I}$ they were $198, \mathrm{I} 22$ or 16.83 per cent. of all the inhabited houses. In $185 \mathrm{I}$ the percentage rose to 27.06 , in 1861 to 32.65 , in 1881 to $4 \mathrm{I} .45$, and in I 891 to 48.76 . In I9OI the number of houses of this class was 349,662 or $5^{6}$ of every Ioo houses of all classes.

First class houses in rural districts in 1841 numbered I 5,978 or I. 36 per cent. Notwithstanding the decrease in the population, the number and percentage of these houses increased at each successive Census, till in I9OI they were 38,700 or 6.17 per cent. of the total inhabited houses. The percentages for the years I $85 \mathrm{I}$, I $86 \mathrm{I}, \mathrm{I} 88 \mathrm{I}$, and $\mathrm{I} 89 \mathrm{I}$ were respectively $2.48,3.09,4.6 \mathrm{I}$, and $5 \cdot 54$.

I append a Diagram exhibiting, according to the graphic method, the percentage of houses in the several classes in the Rural Districts of Ireland in $184 \mathrm{I}, 186 \mathrm{I}, 188 \mathrm{I}$, and 1901 respectively. 


\section{INHABITED HOUSES OF EAOH OLASS IN RURAL DISTRIOTS.}

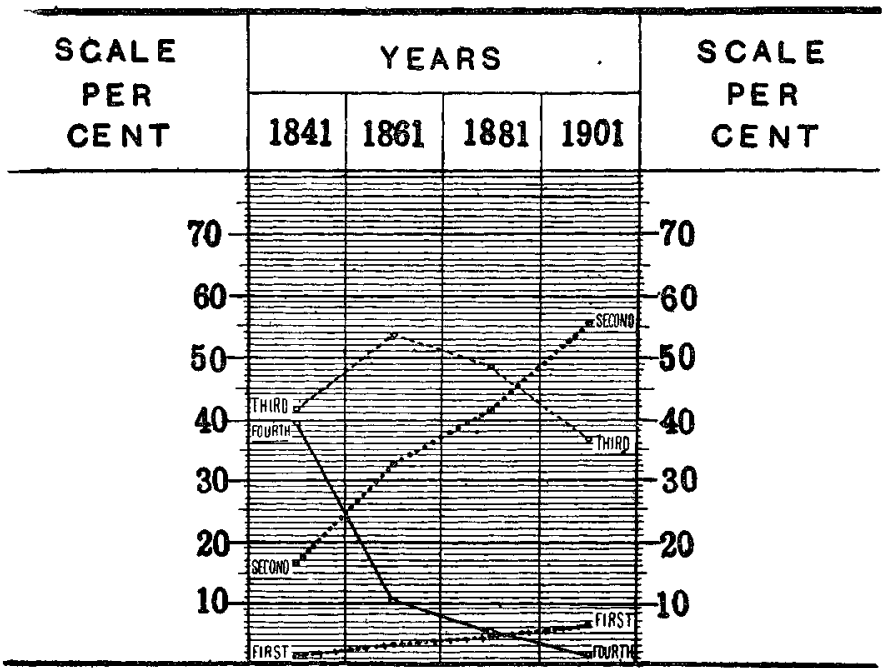

House Accommodation.

I now pass to the second branch of my subject, viz., house accommodation.

In connection with their scheme of House classification the Commissioners for taking the Census of I 84 I devised an arrangement for classifying house accommodation which has been adopted since that date.* Under this plan the accommodation has been arranged under four classes, viz:-

First Class accommodation consisting of first class houses occupied by one family.

Second Class accommodation consisting of second class houses occupied by one family, or of Ist class houses occupied by two or three families.

Third Class accommodation, comprising third class houses with one family each, or second class houses with two or three families, or first class houses occupied by four or five families.

Fourth Class accommodation includes all fourth class houses, third class houses with more than one family, second

* See note on page 196. 
class houses with four or more families, and first class houses inhabited by six or more families.

\section{Whole of Ireland.}

In I 84 I the number of families having only fourth class accommodation formed 42.46 per cent. of the total number of families in the country. In I85 I the percentage fell to 23.60 , and in 1861 to 17.46 . In I90I the percentage of families having fourth class accommodation was only 4.53 , or little more than one-tenth of the percentage in 1841 .

In $184 \mathrm{I}$ the percentage of families having third class accommodation was 39.00 . This rose in 1851 to 48.86 , and in $186 \mathrm{I}$ to 49.06 , since which date it has shown a decline. In I90I the percentage was 3I.64.

There has been a steady increase in the proportional number of families having accommodation of the second class in the period I84I-I90I. Thus in I84I only I6.4I per cent. of the total number of families had second class accommodation, while the percentage rose to 24.27 in $185 \mathrm{I}$, and to 29.55 in 1861 . In I 88I it was 40.59 , and in I90I, 56.37.

Again, while in 1841 the percentage of families enjoying Ist class accommodation was only 2 . I 3 , the relative figure rose gradually till in I9OI it reached 7.46 per cent.

\section{Civic Districts.}

Turning to the house accommodation in Civic Districts, we find that the number of families having only fourth class accommodation was, in I $84 \mathrm{I}, 86,067$ or 36.67 per cent. of the total number of families, and that the percentage gradually diminished till in $190 \mathrm{I}$ the number of families with accommodation of the lowest class was 29,354, the percentage being 10.58 , or little more than onefourth of the percentage in $\mathrm{I} 84 \mathrm{I}$.

The number of families having accommodation of the third class in I $84 \mathrm{I}$, was 79,545 or 33.89 per cent. This percentage increased in $185 \mathrm{I}$ to 35.89 , and in $186 \mathrm{I}$ to 37. I6. In $188 \mathrm{I}$ it had fallen to $3 \mathrm{I} .78$, and in I9o it was only 19.32 -the decline in the later periods is happily due to an increase in the relative number of families having second class accommodation.

In $184 \mathrm{I}, 52,526$ families, or 22.38 per cent., had accommodation of the second class. This percentage has steadily increased, and in I9OI it reached 59.2I.

The percentage of families in the CivicDistricts occupying first class accommodation rose materially during the 


\section{1}

HOUSE-ACCOMMODATION.

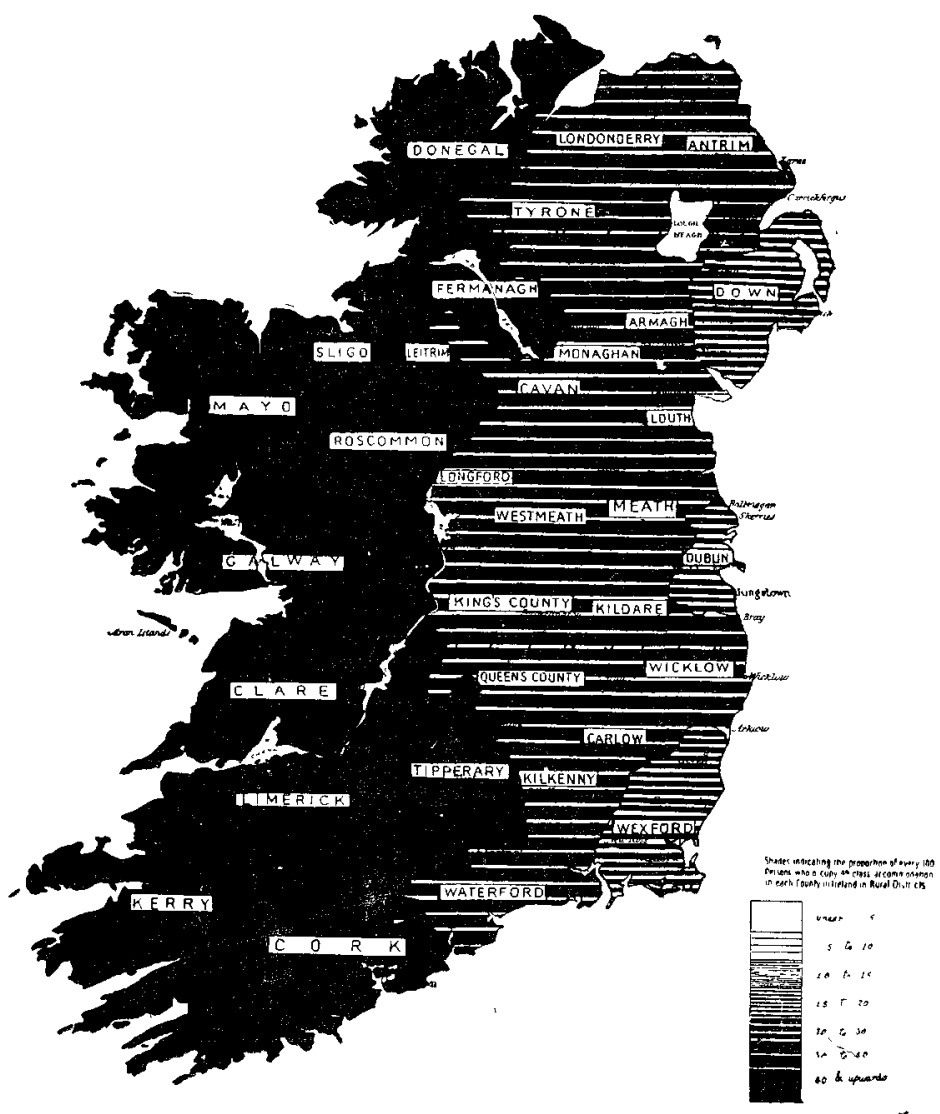




\section{1}

HOUSE-ACCOMMODATIOA.

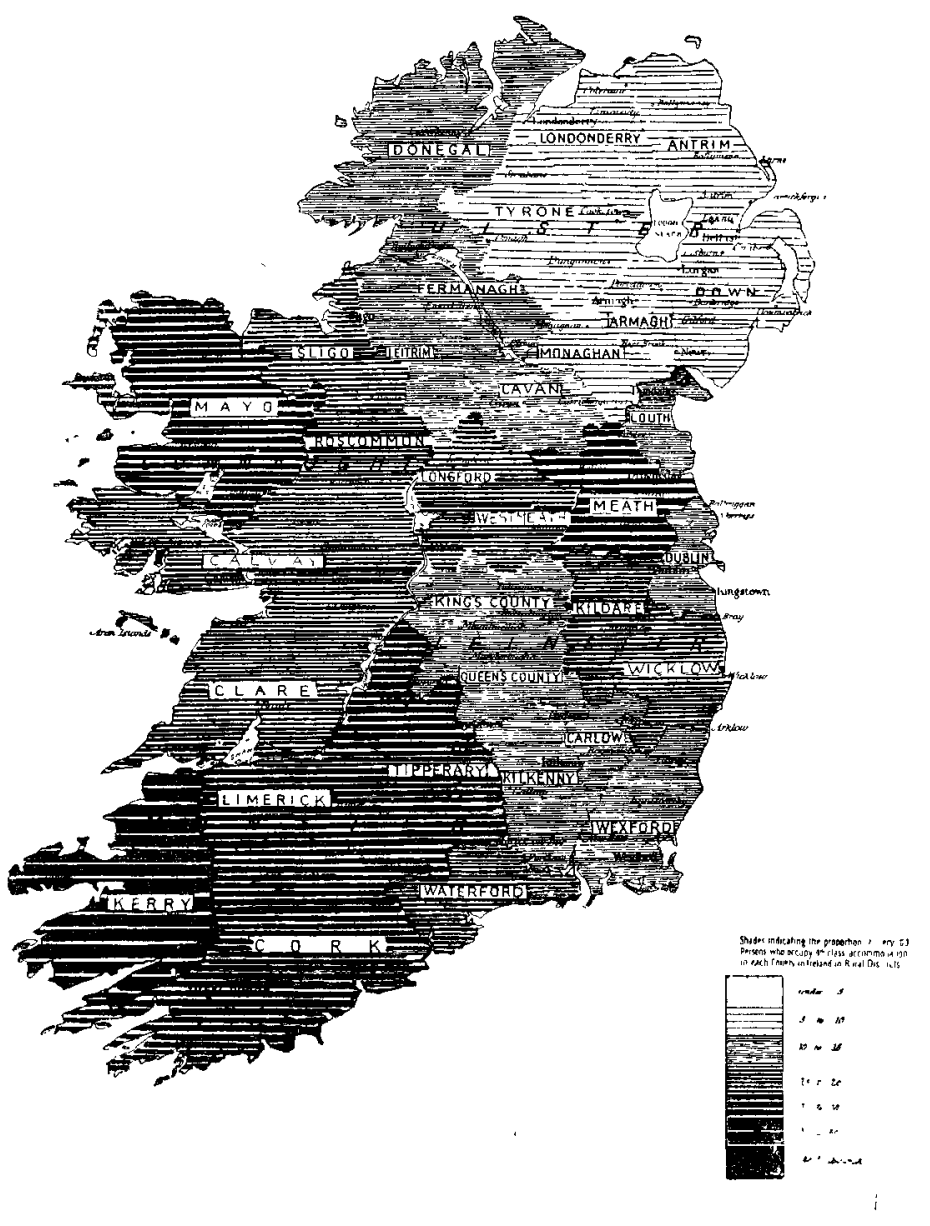


period I84I-I90I. In I84I it was 7.06, while in I90 I it had risen to 10.89 .

\section{Rural Districts.}

In the Rural Districts of Ireland in I 84I, 539,289 families or 43.56 per cent. of the families in those Districts, had but fourth class accommodation. In $185 \mathrm{I}$ the percentage had fallen to 21.77 , in $186 \mathrm{I}$ it was but $\mathrm{I} 5 . \mathrm{I} 6$, in $\mathrm{I} 88 \mathrm{I}$ it further declined to 6.66 per cent., and in 1891 to 3.70 . The percentage in I90I was only I.88, or less than onetwentieth of the percentage in I84I.

In $\mathrm{I} 84 \mathrm{I}$ in the Rural Districts there were $494,84 \mathrm{I}$ families with third class accommodation, being 39.97 per cent. of the total number of families in those districts in that year. In I85I the corresponding percentage rose to $52.1 \mathrm{I}$, and in $186 \mathrm{I}$ to 52.40 , while in $188 \mathrm{I}$ it fell to 48.94 , in $189 \mathrm{I}$ to $43.3 \mathrm{I}$, and in IgOI to 37.04 . Here, as in the Civic Districts, the decrease in the later years was accompanied by an increase in the percentage of families having second class accommodation.

There were only I 5.28 per cent. of the families in Rural Districts in $\mathrm{I} 84 \mathrm{I}$, who had second class house accommodation (the actual number of such families being 189,138 ). In I $85 \mathrm{I}$ the percentage had risen to $24.0 \mathrm{I}$, in $\mathrm{I} 86 \mathrm{I}$ it rose to 29.70 , in 1881 to 40.07 , in 1891 to 47.74 , and in 1901 to $55 . \mathrm{I} 2$, or nearly quadruple the percentage in $\mathrm{I} 84 \mathrm{I}$.

In the Rural Districts of Ireland in $184 \mathrm{I}$ there were only i 4,768 families who enjoyed first class house accommodation, this number representing only I. I9 per cent of the total number of families in those Districts. In $185 \mathrm{I}$ the percentage was 2 . II, and it further rose to 2.74 in I86I, to 4.33 in $\mathrm{I} 88 \mathrm{I}$, to 5.25 in $\mathrm{I} 89 \mathrm{I}$, and to 5.96 in I9OI, being five times the percentage of families having first class accommodation in the rural districts in $\mathrm{I} 84 \mathrm{I}$.

Analysing the returns for the Rural Districts in I9OI by counties, it is found that the percentage of families having first class accommodation in Ireland in I9OI ranged from 2.3 for Mayo to 13.7 for Dublin.

The families having second or third class accommodation formed 92 . I per cent. of the total number of families in the rural districts, the range of variation in the several counties being only from 82.9 per cent. for Dublin to 95.6 for Mayo.

The county percentages for fourth class accommodation ranged from 0.5 for Down to 5.3 for Kerry.

I have constructed a series of Maps shaded so as to illustrate the changes which have taken place since I84I 
in the percentage of families having fourth class accommodation in the Rural Districts of the several counties. These maps I have now the honour to submit to the Society.

It will be observed from the Map for $184 \mathrm{I}$, (facing page 9), that in the whole of the western half of the country, the families having fourth class accommodation formed 40 or more per cent. of the total number of families in the rural districts in that year, and, that, with the exception of the Counties of Down, Dublin, and Wexford, in which the percentage ranged between 20 and 30 , in the whole of the rest of the country the families having only fourth class accommodation formed from 30 to 40 per cent. of the total number of families.

An inspection of the Map for I 86I (facing page I0) shows a great improvement, there being only one County-Kerryin which the percentage of families having fourth class accommodation amounted to 30 per cent. of the total families. In Mayo, Limerick, Tipperary, Cork, and Meath, the percentage ranged between 20 and 30 ; in nine counties it was from I 5 to 20 ; in eleven it was from ro to under I5, while in six it did not reach IO.

The Map, (facing page II), exhibiting the state of things twenty years later than the preceding, that is in $188 \mathrm{I}$, shows a further great improvement, there being only two counties - Kerry and Limerick-in which the percentage of families having fourth class accommodation reached io. In twenty-two counties the percentage ranged between 5 and IO, and in the remaining eight it was under 5 .

Passing over another period of twenty years, bringing us practically down to the present time, the Map for the year IgoI (facing this page), shows a marked improvement when compared with that for $\mathrm{I} 88 \mathrm{I}$, as the highest percentage of families having accommodation of the fourth class was 5.3 only, and this was confined to one County-Kerry-the percentage for all the other counties being less than 5 . In eighteen of these it was less than 2 ; and in one-Downit was only 0.5 .

\section{Enumeration of Tenements of less than Five Rorms.}

I now pass to the subject of tenements of less than five rooms, the enumeration of which formed the special feature of the house accommodation portion of the Census of I 901 .

The total number of occupiers of such tenements in Ireland in Igor was 682,434 or 75.0 per cent. of the total 


\section{1 \\ HOUSE -ACCOMMODATION.}

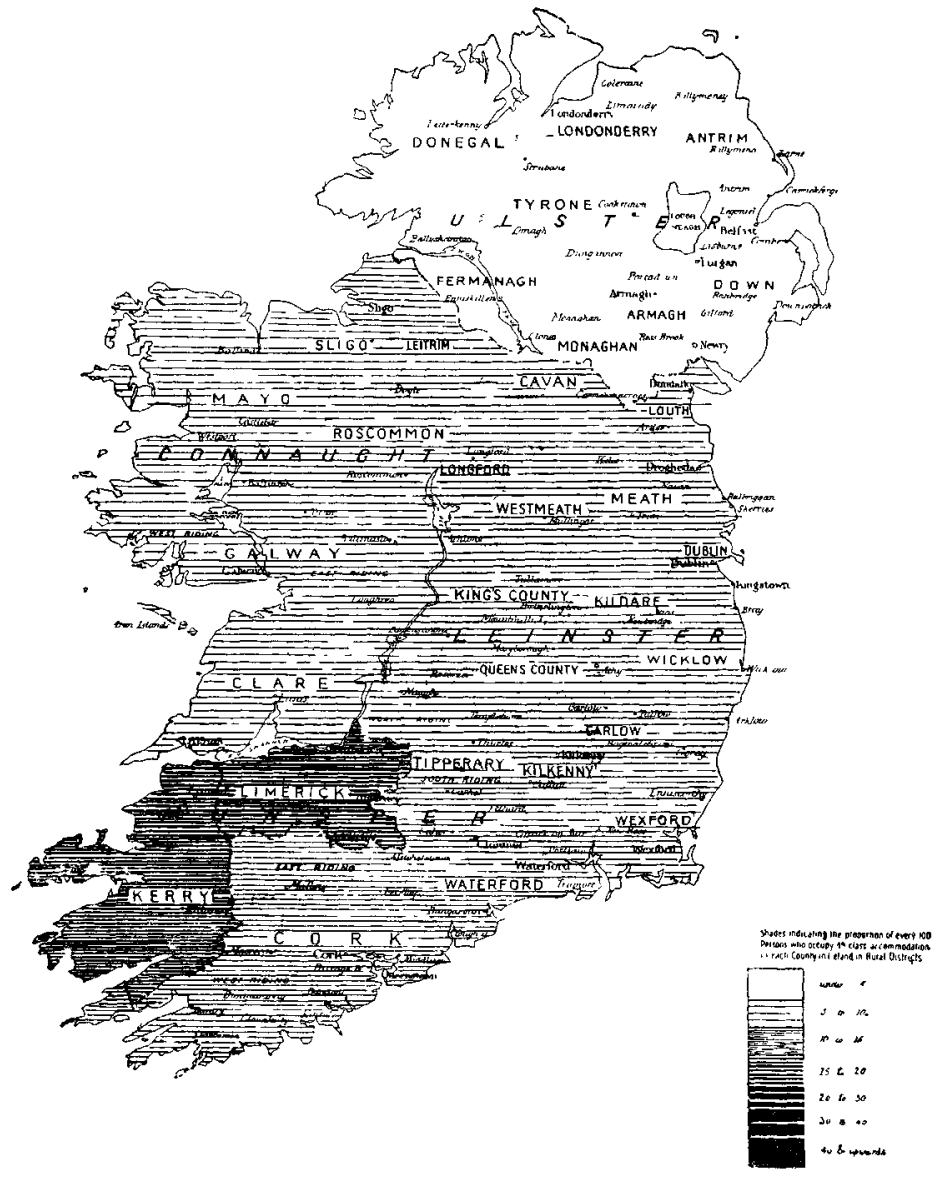


HOUSE-ACCOMMODATION.

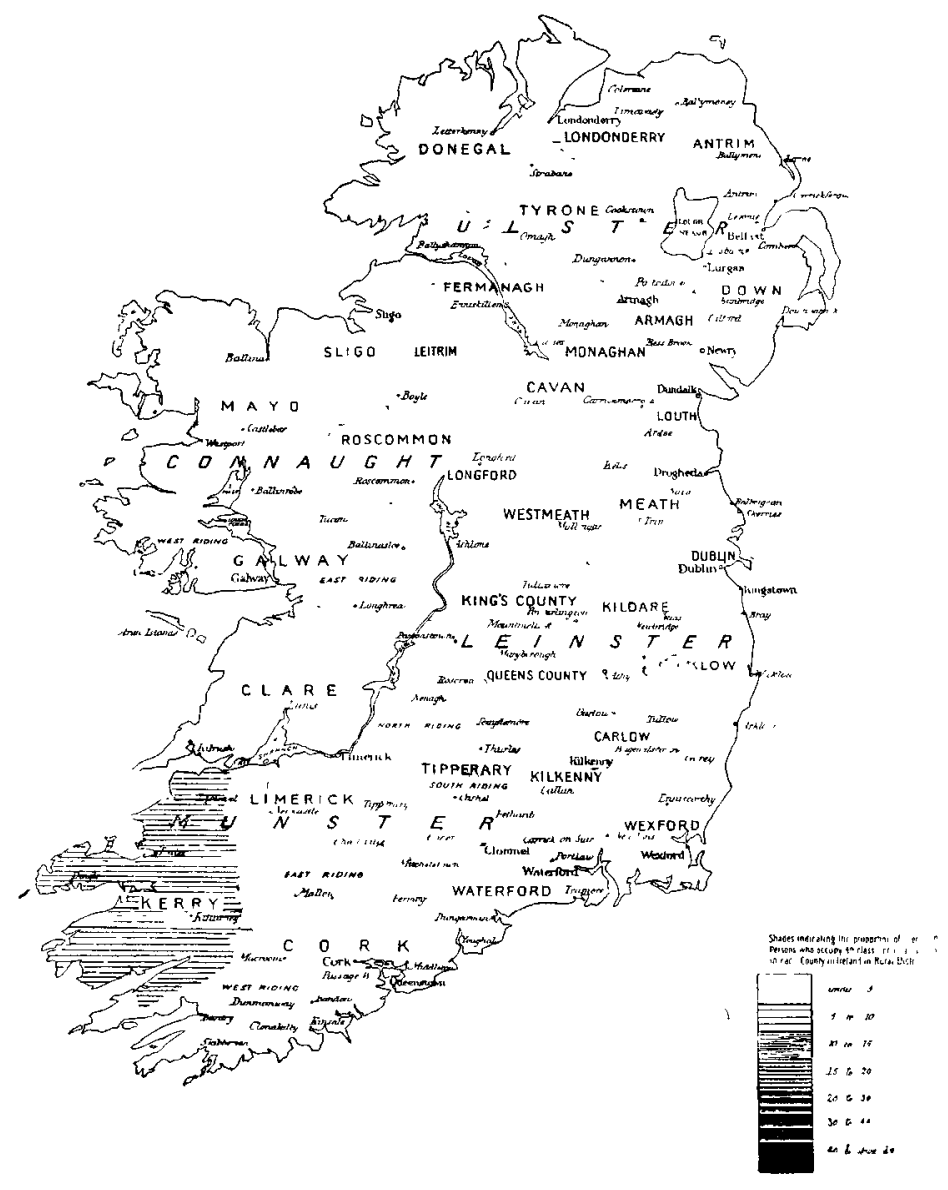


number of families in the country, and of these, 361 were occupiers of part of a room only, 78,988 or 8.7 per cent. of all families were occupiers of one room, 242,7 IO or 26.7 per cent. occupiers of two rooms, 224,769 or 247 per cent. occupiers of three rooms, and I 35,606 or I4 9 per cent occupiers of four rooms.

The number of occupiers of less than five rooms in the Province of Leinster, was 176,872 or 73.9 per cent. of the number of families in the province, and of these, 176 were occupiers of but a part of a room, 33,499 were in one room tenements, 58,144 had two rooms, 52,164 were occupiers of three rooms, and 32,889 occupied four rooms

In Munster the number of tenements of less than five rooms was 157,9 IO or 77 I per cent of the families in the Province, the distribution being as follows .-Part of a room I 32 , one room $I 7,920$, two rooms 54,130 , three rooms $5^{2} 303$, and four rooms 33,425 .

In Ulster the number of occupiers of less than five rooms was 233,574 or 70.0 per cent. of the total number of families in the Province; this number being composed of 29 cases, where the occupier had but part of a room, I 7, I 76 single room tenements, 82,893 cases of two rooms, 73,2 I I tenements of three rooms, and 60,265 where there were four rooms in the tenement

The number of occupiers with less than five rooms in Connaught was II, 078 or 89.5 per cent. of the total number of families in the Province, the I I 4,078 tenements consisting of 24 cases in which the occupier had but part of a room, 10,393 tenements of one room, 47,543 two room tenemer 47,09 I tenements of three rooms; and 9,027 cases where there were four rooms in the tenement.

From these figures we deduce the fact that in Ulster, the tenements occupied by 30 per cent. of the families in the Province, consisted of five or more rooms, and that the corresponding percentage in Leinster was 26. I ; in Munster 22.9, and in Connaught 10.5, only, or little more than one-third of the percentage for Ulster.

\section{T'enements of One Room.}

The most interesting statistics in connection with the enumeration of tenements of less than five rooms are those showing the number of occupants of tenements of one room.

The total number of such tenements in Ireland in 1901, was 79,149, of these there were 20,994 cases, in which the room had but one occupant, 41,918 where the room had two, three or four occupants, I 3,35 I in which there were five, s1x, or seven occupants, and 2,886 in which there 
were eight or more occupants, including 786 cases of nine persons, 364 of ten persons, I 38 of eleven persons, and 68 of twelve or more persons in the room. The total number of cases in which there were five or more persons in the room was 16,237 , and the number of persons inhabiting such rooms was Ior,845 or 2.3 per cent. of the total population of the country.

In the Province of Leinster the total number of tenements of one room was 33,576 . There were 7,562 cases in which one person occupied the room; 18,9 IO cases in which the occupants numbered two, three or four persons, 6,184 cases in which they numbered 5,6 , or 7 persons, and 920 cases in which they numbered eight or more persons These last included 544 cases where the room was occupied by eight persons; 245 where it was tenanted by nine persons ; 91 where it was tenanted by ten persons ; twentyeight cases where the occupants numbered eleven persons, and twelve cases of twelve or more persons in the room

The total number of cases in the Province in which the room was inhabited by five or more persons was 7,104, and the number of persons in these families was 43,085 or 3.74 per cent. of the total population of the Province.

In the Province of Munster the total number of one room tenements was 17,979 . In 4,895 of these tenements the room was occupied by one person only. There were 9,439 cases where it was occupied by two, three, or four persons , 2,874 cases where the occupants numbered five, six, or seven persons, and $77 \mathrm{I}$ cases where they numbered eight or more persons, including 368 cases of occupation by eight persons, 225 by nine persons, I0 4 by ten persons, 39 by eleven persons, and 35 by twelve or more persons. The cases where there were five or more persons in the room numbered 3,645 , and these families consisted of 23,459 persons or 2 i 8 per cent. of the population of the Province.

There were 17,189 one-room tenements in the Province of Ulster, viz :-5,706 cases where the room was in the occupation of one person; 8,395 where there were two, three, or four occupants; 2,479 cases in which the occupants numbered five, six, or seven persons, and 609 where they numbered eight or more persons The last number was composed of 317 cases of eight persons, I64 cases of nine persons; 78 cases of ten persons; 37 cases of eleven persons, and I 3 cases in which the occupants numbered twelve or more persons. The number of cases in which the room was occupied by five or more persons was 3,088 , and the persons forming these families numbered 19,623 or 1.24 per cent. of the total population of the Province. 
In the Province of Connaught the number of one room tenements was 10,405 This total was composed of 2,831 cases where one person was in occupation of the tenement, 5, I 74 where there were two, three, or four persons, I , 8 14 where there were five, six or seven persons, and 586 cases where there were eight or more occupants of the room, including 301 cases of occupation by elght persons, 152 by nine persons, $9 \mathrm{I}$ by ten persons, 34 by eleven persons, and 8 by twelve or more persons. The cases in which there were five or more persons in the room numbered 2,400 , and the occupants numbered 15,678 or 2.42 per cent. of the population of the Province.

\section{Comparative Statrstics of England and Scotland.}

It is, unfortunately, impossible to compare the figures for Ireland in Igor with previous statistics, as the recent Census was the first in which inquiry into the number of occupants of tenements of less than five rooms was made A comparison can, however, be instituted for the whole country in 1901 with similar returns for England and Scotland

The number of tenements of one room in England and Wales in I901 was 251,667 or 3.6 per cent. of the total number of tenements-of these, 107,8 I9 were occupied by one person; 77, I 79 by two persons ; 55,8 I 3 by three or four persons ; and Io,856 or o. I 5 per cent of all tenements by five or more persons, the occupants of these 10,856 rooms, numbering 60,044 or 0.18 per cent. of the total population.

The number of tenements of one room in Scotland in I90I was 169,798 or 17.5 per cent, of the total number of tenements. These comprised 45,266 cases of tenements occupied by one person, 4I,279 cases of two occupants, 51,700 where three or four persons were in occupation, and 31,553 or 3.27 per cent. of the total number of tenements of all classes, where the occupants numbered five or more, the total number of persons in the last group being 188,049 or 4.20 per cent. of the total population of the country.

Comparing these figures we find that as regards the percentage of the tenements of all classes which were one room tenements occupied by five or more persons, the three countries stand thus :-

England

Scotland

Percentage.

Ireland

o 15

3.27

I. 78

The actual state of things in each country will be more 
evident if we compare the number of persons in the one room tenements, having five or more occupants with the total population of all classes.

We find that in England of a total population of $32,527,843$ there were only 60,043 persons or 0.18 per cent., who were inhabitants of one room tenements having five or more occupants each. In Ireland the corresponding percentage was 2.28, and in Scotland 4.20.

\section{Tenements of One Room in the Shx County Boroughs of Ireland.}

I shall now refer to the one room tenements in the s1x County Boroughs of Ireland

In Dublin, of the total number of 59,263 families, 21,747 or 36.70 per cent. were located in one room tenements.

In 3,278 of these cases or 553 per cent of the total number of families, the family consisted of one person only, in 5,544 or 936 per cent there were two persons in the family, in 7,776 cases or 13.12 per cent there were three or four persons in the family; in 4,576 or 7.72 per cent, there were five, six or seven, and in 573 cases or 0.97 per cent, the family consisted of eight or more persons each, including I 45 of nine persons, 47 of ten persons, I 3 with eleven, and six in which there were twelve or more occupants of the single room. The total number of persons in the families of five or more persons in one room tenements was 30,837 or 10.61 per cent. of the total population of the city.

The total number of families in Belfast was $69,98 \mathrm{I}$, and of these there were only 697 or $I$ oo per cent. in tenements of one room. Of the 697 cases, there were 307 or 0.44 per cent. in which the family consisted of one person only, in 190 or 0.27 per cent. there were two persons in the famlly, in 140 or 0.20 per cent. there were three or four persons, and in the remaining 60 cases or 0 og per cent, the family consisted of five, s1x, or seven persons. The total number of individuals in the 60 families of five or more persons in one room tenements in Belfast was 334 , or only o 10 per cent. of the total population of the city.

It will be observed that there is a vast disparity between the proportion of one room tenements in Belfast and the corresponding proportion in Dublin, and that in Belfast there is very little overcrowding in single room tenements.

In Cork, of I 5,255 families, 1,620 or 10.62 per cent. were located in tenements of one room, of these 1,620 tenements, 527 or 3.40 per cent. of the tenements of all classes were occupied by one person, 
$44 \mathrm{I}$ or 2.89 per cent. by two persons, 478 or $3 . \mathrm{I} 3$ per cent by three or four persons; I 57 or 1.03 per cent. by five, sIx, or seven persons; and I 7 or $O$ I I per cent. by eight or more persons, the total number of persons in the one room tenements having five or more occupants each being $\mathrm{r}, 022$ or I 34 per cent. of the population of the city

In Londonderry County Borough, the number of families inhabiting tenements of one room was 529 or 7 . I 5 per cent, I 3I or I 77 per cent of the total number of tenements were occupied by one person, I93 or 2 6I per cent. by two persons, 165 or 2.23 per cent by three or four persons, 34 or o 46 per cent by five, six, or seven persons, and there were six cases where there were eight or more persons in occupation of the room. The 40 rooms in each of which there were five or more persons had 24I occupants, being 060 per cent of the population of the city

In Limerick, I, I66 families, or I 580 per cent of the total number occupied tenements of one room. including 302 cases or 409 per ceint where there was one occupant, 338 or 4.58 per cent where there were two occupants, 321 or 435 per cent where there were three or four occupants, I 84 or 249 per cent where there were five, six, or seven persons, and 21 cases or 0.29 per cent. where the number of persons was eight or more. The occupants of the rooms with five or more persons each numbered I,249 or 327 per cent. of the population of the city.

The number of families in Waterford in occupation of one room was 368 or 728 per cent There were I 38 cases or 273 per cent where the family consisted of one person, 109 or 2 i6 per cent where it consisted of two persons , 87 or I 72 per cent where there were three or four persons, 30 or 059 per cent. where there were five, s1x, or seven persons, and 4 where there were eight persons or more in the tenement, the total number of occupants of the one room tenements in which there were five or more persons being 204 or 076 per cent. of the population of the city.

Comparing the four cities of Cork, Londonderry, Limerick, and Waterford with reference to the subject of overcrowding in one room tenements, and taking those cases in which there were five or more persons in the room as representing that class, we find that in Limerick it comprised 28 per cent. of the total number of families, and 3.27 per cent of the population of the City, in Cork, I I per cent of the families, and I 34 per cent. of the population, in Waterford, 0.7 per cent of the families, and 076 per cent of the population, and in Londonderry, 0.5 per cent. of the 
families, and 0.60 per cent. of the population, or little more than one-sixth of the corresponding percentage for Limerick.

Comparatıve Statistics for English and Scottısh Cities.

As already stated, there are no previous Irish statistics avallable on the subject of overcrowding, and, therefore, no comparison can be instituted between the state of things in the s1x County Boroughs in I9OI and at an earlier date I have, however, thought it well to bring before the Society the figures relating to this matter for a few cities in England and Scotland

In London of a total of I,0I9,646 tenements, I 49,524, or I4 66 per cent were one room tenements These consisted of 60,421 cases (or 592 per cent of the total number of London tenements), in which the room was occupied by one person only, 48,34 I or 474 per cent. of the total in which there were two occupants in each room, 34,959 or 3.43 per cent. rooms with three or four occupants each, and 5,803 cases or 057 per cent in which there were five or more persons in each room, including $16 \mathrm{I}$ cases of single room tenements having eight or more occupants. The occupants of the rooms having five or more persons in each numbered 31,615 or 0.70 per cent of the total population

In Liverpool the total number of tenements was 138,845 Of these, 8,527 or 6 I 4 per cent were tenements of one room. The tenements of one room included 2,587 cases (or I.86 per cent of the total number of tenements), where the room was occupied by one person, 3, I 8 I cases or 229 per cent in which it was occupied by two persons, 2,457 or I.77 per cent in which it was occupied by three or four persons, and 302 or 0.22 per cent. in which the occupants were five or more in number. In these 302 rooms there were I,6I4 persons, being 0.24 per cent. of the total population of the city.

The total number of tenements in Manchester was I I 2,854. Of this total, 2, I 40 or I.90 per cent. were tenements of one room. These one room tenements comprised 820 cases or 073 per cent. where the room was occupied by one person ; 870 or 0.77 per cent where it was occupied by two persons, 405 or o 36 per cent where the tenants numbered three or four persons, and 45 cases where there were five or more persons in occupation The number of persons in these 45 rooms was 26I or only 0 o5 per cent of the total population

Turning to Scotland, in Edinburgh out of a total of 7 I,504 tenements of all kinds, I 2, I 44 or I 6.98 per cent. 
were tenements of one room only. An analysis shows that in 4,794 cases, or 670 per cent. the room was occupied by one person, in 3, I I 2 cases, or 435 per cent., it was inhabited by two persons; in 2,950 instances, or 4 I 3 per cent, there were three or four persons in occupation; whilst in I, 288 cases, or I 80 per cent., the occupants numbered five or more persons, the total number of persons in these 1,288 rooms amounting to 7,360 or 2.33 per cent. of the population of Edinburgh

In Glasgow, where the total number of tenements of all descriptions was 163,258 , there were 42,623 tenements or 26.1 I per cent. of one room. These consisted of 8,603 cases or 5.27 per cent of the total, in which the room was occupied by one person, 12,029 or 7.37 per cent. where it was inhabited by two persons. I 5,002 cases or 9 I9 per cent. where it was inhabited by three or four persons; and 6,989 cases or 428 per cent where the occupants were five or more in number. The total number of occupants in these 6,989 cases amounted to 39,880 or 5.24 per cent of the population of the City.

The following statement shows succinctly the relative overcrowding in one room tenements in the cities above referred to. It will be observed that Dublin occupies the unenviable position of being by far the worst in this re spect -

$\begin{array}{ll} & \begin{array}{l}\text { Number of one room } \\ \text { Tenements having five } \\ \text { or morc occupants } \\ \text { each, in every IOo } \\ \text { tenements of all classes }\end{array} \\ \text { Citres. } & \end{array}$

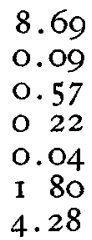

Number of Persons in one Room Tenements with five or more occupants in every 100 of the total population
I0.6I*
0.10
0.70
0.24
0.05
2.33
524

In bringing this paper to a close, I would say that the material improvement in the housing of the people of Ireland since $\mathrm{I} 84 \mathrm{I}$ is very satisfactory, but there is still much to be accomplished.

* As stated, this percentage bas reference to the County Borough of Dublin-being the City as extended under the Dublin Corporation Act, 1900 Taking the whole of the Dublin Registration Area-which consists of the City of Dublin, and the Urban Districts of Rathmines, Pembroke, Blackrock and Kingstown-the number of persons in the one room tenements, having five or more occupants in every roo of the total population, was 87 
The substitution of the modern labourers' cottages in the rural districts for the mud cabins formerly so numerous and the erection of Artisans' Dwellings in some of the larger urban districts have done much to provide suitable habitations for the people, but the statistics of tenements of one room show that in many parts of the country a considerable proportion of the population are still exposed to all the evils resulting from overcrowding. The total effacement of fourth class houses and the reduction of the number of cases of families having only fourth class accommodation should be aimed at.

It is gratifying to know that this pressing subject is at present attracting earnest attention in Dublin. The action of the Municipal Council for some years past has resulted in a very considerable change for the better in several parts of the City, and great good has been effected through the princely munificence of Lord Iveagh

The movement for the improvement of the dwellings of the poor has recently received an important impetus by reason of the great practical interest manifested in it by His Excellency the Lord Lieutenant, who has by personal inspection acquired a full knowledge of the necessities of the case, and it may be confidently hoped that the efforts now being made will, ere long, result in a substantial amelioration of the sad condition of the humbler classes in so far as regards their house accommodation.

In conclusion, I desire to express my warm thanks to Mr. Peter J. O'Neill, Honorary Treasurer of the Society, and one of the Superintendents in my Department, for his very kind aid in the preparation of this paper. 